\title{
Analysis of the Development of the Industrial Sector in the Context of Global Transformation of Economic Processes
}

\author{
Maria Klevtsova ${ }^{1}$, Yulia Vertakova $^{1}$, and Yulia Polozhentseva ${ }^{1 *}$ \\ ${ }^{1}$ South-West State University, Department of Regional Economics and Management, 305040, 94, 50 \\ let Oktyabrya str., Kursk, Russia
}

\begin{abstract}
.
Research background: In the modern world the rate of global transformation of economic processes is constantly increasing, while stimulating the growth of industrial production in the countries of the world. The industrial sector plays an important role in achieving stable growth in national wealth indicators, as well as in ensuring national security. Accelerating the pace of industrial development, especially high-tech, contributes to an increase in employment and the transition to a balanced economic development of the country.

Purpose of the article: The main purpose of the publication is to study the current state and structural transformations in industry in the world economy, to analyze the level and dynamics of the main indicators of industrial development.

Methods: Using statistical analysis of time series and dynamics indicators, the authors have evaluated the development trends of the industrial sector, based on the methods of scientific knowledge, a comparative analysis of the systematic results of development indices characterizing the functioning of industry around the world.

Findings \& Value added: A statistical analysis of the development of the industrial sector in the context of globalization allows the authors to determine the exact number of enterprises, the costs of the industry and their income, as well as the contribution made to the development of both region and the country as a whole. In this research the authors have considered the main economic indicators of industrial development in the world. The authors have systematized the main measures aimed at the development of the industrial sector.
\end{abstract}

Keywords: industrial development; level of business activity; globalization; macroeconomic indicators

${ }^{*}$ Corresponding author klevtsovam@mail.ru 
JEL Classification: $E 60 ; L 60 ; F 6$

\section{Introduction}

The balance and efficiency of the national economy, the presence of economic growth, significantly depend on the development of the industrial complex, its specialization in the international system of division of labor. Numerous conditions and factors of the global transformation of economic processes, among which technical-technological and institutional ones are of the greatest importance, determine the peculiarities of the implementation of transformational changes in the world economy. Modern production chains are changing: production is getting closer to final consumers, logistics and technological costs are being reduced, the social component of projects is changing, and all this contributes to the development of local economic systems.

The transformation of the development of the country's industrial complex in the context of globalization is a multifaceted process that relies on the operational efficiency of industrial enterprises, digital transformation of the industry, cultural transformation (new cultural values, a new model of leaders' behavior), organizational transformation (flexible teams, changed processes, a project approach, creation of a new ecosystem, increase in the number of external and internal partners).

At the moment, industrialized countries have moved to a state where technologies are being scaled up, and not only the introduction of these technologies is scaled, but also a change in the management system that allows companies to operate in a new mode of mass functioning of these technologies. In particular, there are three blocks of such technologies:

1. the use of network integration, which makes it possible to link organizations and almost all units,

2. the use of human capital through a data exchange system;

3. the use of artificial intelligence technologies, which include digitalization and flexible automation technologies.

\section{Methodology and background}

The world leader in terms of industrial production is China, accounting for $28.4 \%$ of world industrial production. The second and third places are occupied by the USA and India. The third place is occupied by Russia, so in 2019 industrial production increased by $2.3 \%$.

Scientists from the entire world community are actively studying the features of the transformation of the development of the industrial complex in the context of the digitalization of the economy. In general, the analysis of economic growth in industry and the study of changes associated with the spread of the concept of Industry 4.0 were carried out by Castiglione, C., Infante, D., Smirnova, J. [1], Chen, J.-H., Chen, Y. [2], Dowlah, C. [3], Vertakova, Y., Polozhentseva, Y., Klevtsova, M. [4], Kuladzhi, Tamara ;Babkin, Aleksandr; Murtazaev, Said-Alvi [5]. Problems associated with the differentiation of the levels of spatial concentration of industrial sectors are considered by such economists as Ács, J. Z., \& Varga, A.[6], Thissen, M., van Oort, F., Diodato, D., \& Ruijs, A. [7], Tregenna, F. [8], Weiss, J. [9], Bodrunov, S., Plotnikov, V. and Vertakova Yu. [10]. Some authors research not only the possibilities of improving and creating new sectors and technologies in industry, but also analyze the possibility of expanding existing ones, including those based on digital technologies (Tregenna F. [11], Westkampter E. [12], Xu, Li Da; Xu, Eric L.; Li, Ling [13], Mueller, J. M.; Kiel, D.; Voigt, K.-I. [14], Dalenogare, L. S.; Benitez, G. B.; Ayala, N. F., Frank, A. G. [15]).

The methodological basis of this study was such general scientific and specific methods as: comparative analysis of sources; analytical method to identify trends in the development 
of Industrial Sector; synthesis method, which allowed to obtain reasonable conclusions; and the inductive method.

The analysis of the factors influencing the development of the industrial sector in the context of global transformation of economic processes showed that it is necessary to consider the development of the spatial potential of the country in the interaction of several groups of factors. Now the main scientific and practical task is the development of methods for assessing the industrial sector in the country. An integral component of the assessment is the system of indicators. For a deeper analysis, we investigated purchasing managers' indexes (PMI) are economic indicators derived from monthly surveys of private sector companies.

\section{Results}

The authors suggest analyzing the development of the industrial sector of the countries worldwide in the context of the global transformation of economic processes based on the study of the dynamics of the main indicators reflecting its development.

First of all, it should be noted that the main and most important indicators when analyzing the industrial sector of both a separate region and the state are gross domestic product (GDP) and gross value added (GVA).

Table 1 shows the dynamics of the gross domestic product of the G7 countries and the Commonwealth of Independent States for 2019, as well as the economic growth rate for the year in review. Also, Table 1 shows the predicted values of the indicators under consideration for 2020, developed by the Institute of Scientific Communications.

Table 1: Real and projected gross domestic product and growth rates of the countries of G7 and the Commonwealth of Independent States

\begin{tabular}{|c|c|c|c|c|}
\hline \multirow{2}{*}{ Country } & \multicolumn{2}{|c|}{ Growth rate, \% } & \multicolumn{2}{c|}{ GDP, billions of dollars } \\
\cline { 2 - 5 } & $\mathbf{2 0 1 9}$ & $\mathbf{2 0 2 0}$ & $\mathbf{2 0 1 9}$ & $\mathbf{2 0 2 0}$ \\
\hline Armenia & 3.000 & 3.100 & 11.778 & 12.369 \\
\hline Azerbaijan & 3.071 & 2.760 & 45.553 & 48.823 \\
\hline Belarus & 0.818 & 2.127 & 58.171 & 60.357 \\
\hline Canada & 1.843 & 1.800 & 1719.451 & 1783.360 \\
\hline France & 1.749 & 1.796 & 2562.275 & 2650.237 \\
\hline Germany & 1.415 & 1.290 & 3617.086 & 3727.659 \\
\hline Italy & 0.800 & 0.800 & 1879.410 & 1922.214 \\
\hline Japan & 0.846 & 0.210 & 5085.741 & 5163.766 \\
\hline Kazakhstan & 2.815 & 3.210 & 188.502 & 204.602 \\
\hline Kyrgyzstan & 5.211 & 4.952 & 7.629 & 8.073 \\
\hline Republic of Moldova & 3.800 & 3.800 & 8.104 & 8.565 \\
\hline Russia & 1.500 & 1.500 & 1654.091 & 1712.024 \\
\hline
\end{tabular}




\begin{tabular}{|c|c|c|c|c|}
\hline Tajikistan & 5.500 & 6.000 & 8.220 & 8.908 \\
\hline Turkmenistan & 5.121 & 5.007 & 52.086 & 57.669 \\
\hline $\begin{array}{c}\text { The United Kingdom of } \\
\text { Great Britain and Northern } \\
\text { Ireland }\end{array}$ & 1.606 & 1.909 & 2607.850 & 2689.841 \\
\hline $\begin{array}{c}\text { The United States of } \\
\text { America }\end{array}$ & 2.121 & 1.825 & 21239.303 & 22063.044 \\
\hline Uzbekistan & 6.000 & 6.000 & 75.553 & 79.742 \\
\hline
\end{tabular}

Sources: Institute of Scientific Communications, Access mode: https://www.archilab.online/

According to the data presented in table 1-2, it can be seen that the three leaders in terms of Gross Domestic Product are the following countries: the United States, Japan, and Germany. The most lagging behind countries among the considered ones are: Tajikistan, the Republic of Moldova and Kyrgyzstan. In predicted values compiled by the Institute of Scientific Communications, the situation with the leading and off-track countries under consideration remains at the same level.

Table 2 Indicators of the value added of the manufacturing industry in \% to GDP by countries for the period from 2010 to 2018

\begin{tabular}{|c|c|c|c|c|c|c|c|c|c|}
\hline Country & $\mathbf{2 0 1 0}$ & $\mathbf{2 0 1 1}$ & $\mathbf{2 0 1 2}$ & $\mathbf{2 0 1 3}$ & $\mathbf{2 0 1 4}$ & $\mathbf{2 0 1 5}$ & $\mathbf{2 0 1 6}$ & $\mathbf{2 0 1 7}$ & $\mathbf{2 0 1 8}$ \\
\hline Azerbaijan & 4.81 & 3.99 & 4.24 & 4.22 & 4.71 & 4.99 & 4.93 & 4.70 & 4.82 \\
\hline Belarus & 22.51 & 26.42 & 24.78 & 22.00 & 21.09 & 20.64 & 20.15 & 21.63 & 21.26 \\
\hline France & 10.33 & 10.40 & 10.36 & 10.35 & 10.28 & 10.43 & 10.28 & 9.99 & 9.71 \\
\hline Germany & 19.70 & 20.23 & 20.16 & 19.93 & 20.22 & 20.38 & 20.74 & 20.56 & 20.40 \\
\hline Italy & 14.23 & 14.21 & 13.85 & 13.88 & 13.98 & 14.40 & 14.80 & 14.95 & 15.05 \\
\hline Japan & 20.83 & 19.67 & 19.73 & 19.44 & 19.73 & 20.81 & 20.68 & 20.73 & .11 \\
\hline Kazakhstan & 11.32 & 11.09 & 11.08 & 10.63 & 10.32 & 10.28 & 11.33 & 11.28 & 11.43 \\
\hline Kyrgyzstan & 16.86 & 18.27 & 12.07 & 15.77 & 13.68 & 14.05 & 15.43 & 14.99 & 15.16 \\
\hline $\begin{array}{c}\text { The Republic of } \\
\text { Moldova }\end{array}$ & 9.95 & 10.56 & 10.65 & 11.19 & 11.60 & 11.96 & 11.90 & 11.55 & 11.27 \\
\hline Russia & 12.82 & 11.58 & 11.80 & 11.32 & 11.48 & 12.48 & 12.01 & 12.22 & 12.31 \\
\hline $\begin{array}{c}\text { Tajikistan } \\
\text { The United }\end{array}$ & - & 9.66 & 9.47 & 9.23 & 7.62 & 8.70 & 9.72 & 10.00 & 10.50 \\
\hline $\begin{array}{c}\text { Kingdom of } \\
\text { Great Britain and } \\
\text { Northern Ireland }\end{array}$ & 9.55 & 9.47 & 9.37 & 9.58 & 9.38 & 9.30 & 9.10 & 8.98 & 8.84 \\
\hline $\begin{array}{c}\text { The United } \\
\text { Atates of } \\
\text { America }\end{array}$ & 11.93 & 11.95 & 11.85 & 11.81 & 11.64 & 11.62 & 11.12 & 11.15 & $\mathrm{NA}$ \\
\hline
\end{tabular}

Sources: The World Bank Group, Access mode: https://www.worldbank.org/ 
Analyzing the indicators of the added value of the manufacturing industry as a percentage of the gross domestic product during the study period, all the countries under review have an ambiguous development tendency. The highest values of the studied indicator can be traced in the following countries: Belarus, Germany, and Japan. This suggests that the manufacturing sector makes a significant contribution to the development of the country's gross domestic product. The Russian Federation, in turn, has a stable development situation for the indicator under study. Its values during the study period have minor fluctuations in indicators. Thus, the added value of the manufacturing industry in 2018 amounted to $12.31 \%$ of the gross domestic product.

Table 3 Indicator of industrial production by countries in the period from 2010 to 2018, billion US dollars

\begin{tabular}{|c|c|c|c|c|c|c|c|c|c|}
\hline Country & 2010 & 2011 & 2012 & 2013 & 2014 & 2015 & 2016 & 2017 & 2018 \\
\hline Belarus & 27.1 & 56.4 & 99.9 & 98.3 & 109.4 & 120.1 & 132.8 & 151.0 & 178.6 \\
\hline France & 369.2 & 378.3 & 369.2 & 366.7 & 362.6 & 368.8 & 371.0 & 378.3 & 379.7 \\
\hline Canada & 219.8 & 230.3 & 220.0 & 233.9 & 245.6 & 244.4 & 244.3 & 257.6 & 266.1 \\
\hline Italy & 535.9 & 538.1 & 506.0 & 490.4 & 485.1 & 493.6 & 500.3 & 515.8 & 522.7 \\
\hline Germany & $\begin{array}{c}1094 . \\
6\end{array}$ & $\begin{array}{c}1171 . \\
5\end{array}$ & $\begin{array}{c}1162 . \\
6\end{array}$ & $\begin{array}{c}1160 . \\
8\end{array}$ & $\begin{array}{c}1176 . \\
5\end{array}$ & $\begin{array}{c}1193 . \\
6\end{array}$ & $\begin{array}{c}1209 . \\
4\end{array}$ & $\begin{array}{c}1242 . \\
2\end{array}$ & 1254 \\
\hline Japan & $\begin{array}{c}1802 . \\
9\end{array}$ & $\begin{array}{c}1750 . \\
2\end{array}$ & $\begin{array}{c}1761 . \\
5\end{array}$ & $\begin{array}{c}1735 . \\
8\end{array}$ & $\begin{array}{c}1765 . \\
9\end{array}$ & $\begin{array}{c}1743 . \\
5\end{array}$ & $\begin{array}{c}1744 . \\
5\end{array}$ & $\begin{array}{c}1793 . \\
8\end{array}$ & 1813.2 \\
\hline Kazakhstan & 68.8 & 71.1 & 71.5 & 72.4 & 72.5 & 71.34 & 69.6 & 75.4 & 77.7 \\
\hline Moldova & 1.8 & 1.9 & 1.9 & 2.10 & 2.3 & 2.27 & 2.3 & 2.37 & 2.5 \\
\hline Russia & 503.0 & 528.5 & 546.7 & 556.4 & 569.8 & $\begin{array}{c}565.1 \\
0\end{array}$ & 577.6 & 589.5 & 606.6 \\
\hline $\begin{array}{l}\text { The Unites } \\
\text { States of } \\
\text { America }\end{array}$ & $\begin{array}{c}2988 . \\
9\end{array}$ & $\begin{array}{c}3082 . \\
0\end{array}$ & $\begin{array}{c}3175 . \\
2\end{array}$ & $\begin{array}{c}3239 . \\
6\end{array}$ & $\begin{array}{c}3339 . \\
0\end{array}$ & $\begin{array}{c}3305 . \\
7\end{array}$ & $\begin{array}{c}3241 . \\
0\end{array}$ & $\begin{array}{c}3316 . \\
2\end{array}$ & 3446 \\
\hline $\begin{array}{l}\text { The United } \\
\text { Kingdom } \\
\text { of Great } \\
\text { Britain and } \\
\text { Northern } \\
\text { Ireland }\end{array}$ & 463.5 & 460.7 & 448.2 & $\begin{array}{c}445.0 \\
6\end{array}$ & 451.8 & $\begin{array}{c}457.1 \\
7\end{array}$ & 461.6 & $\begin{array}{c}466.5 \\
6\end{array}$ & 471.3 \\
\hline
\end{tabular}

Sources: The World Bank Group, Access mode: https://www.worldbank.org/

On the basis of the data presented in Table 3, it is possible to draw the following conclusions:

- The following countries demonstrate the largest values of the studied indicator: Germany, Japan and the United States. In these countries the concentration of industrial production is significant, in contrast to the rest of the number of countries under consideration;

- The indicators of industrial production in the Russian Federation show a positive growth trend throughout the entire study period. So in 2018 this figure is 606.69 billion US dollars, which is $20.61 \%$ more than in the reference year 2010 . In terms of the studied indicator The Russian Federation ranks next in a number of countries under review, immediately following the leaders. 
Purchasing Managers' Index (PMI) considers the state of the economy in both the manufacturing and service sectors. This indicator is calculated based on the results of surveys of top managers of manufacturing companies and enterprises, business representatives, as well as purchasing managers in the service sector.

When analyzing the PMI indicator, it is possible to predict the dynamics of economic trends. The purchasing managers' index is studied both for assessing changes and for forecasting and planning in matters of new production orders, industrial production, employment, as well as wholesale stocks. Table 4 presents the current data on the purchasing managers' index for April-May 2020.

Table 4 Purchasing managers' index by countries for April-May 2020

\begin{tabular}{|c|c|c|}
\hline Country & May 2020 & April 2020 \\
\hline Australia & 28.1 & 21.7 \\
\hline Brazil & 28.1 & 26.5 \\
\hline China & 54.5 & 47.6 \\
\hline France & 32.1 & 11.1 \\
\hline Germany & 32.3 & 17.4 \\
\hline Ghana & 46.7 & 31.7 \\
\hline India & 14.8 & 7.2 \\
\hline Italy & 33.9 & 10.9 \\
\hline Japan & 27.8 & 25.8 \\
\hline Kazakhstan & 15.3 & 42.1 \\
\hline Mozambique & 40 & 37.1 \\
\hline New Zealand & 38.2 & 23.8 \\
\hline Niger & 40.7 & 40.7 \\
\hline Russia & 35 & 13.9 \\
\hline Singapore & 27.1 & 28.1 \\
\hline South Africa & 32.5 & 35.1 \\
\hline Uganda & 41.9 & 21.6 \\
\hline Great Britain & 30 & 13.8 \\
\hline USA & 37 & 27 \\
\hline Zambia & 34.8 & 37.3 \\
\hline
\end{tabular}

Sources: Ministry of Economic Development of the Russian Federation, Access mode: https://www.economy.gov.ru, Ministry of Economic Development of the Russian Federation, Access mode: https://www.economy.gov.ru 
Based on the data presented in Table 4, it is clearly seen that today basically all countries have a negative downward trend in business activity, with the exception of China. In China, the May 2020 PMI shows positive growth compared to the previous month. Despite the negative trend of purchasing managers' index by countries, due to the current unstable economic situation amid the ongoing impact of the coronavirus disease 2019 (COVID-19) outbreak, it can be noted: in comparison with the considered indicator for April 2020 in May 2020, the majority countries demonstrate a significant increase in this indicator. This indicates an improvement in the current economic situation of industrial facilities.

When analyzing the purchasing managers' index, it is necessary to understand that its main drawback is that it is formed from the private opinions of individuals, and its data are not clear quantitative, but rather an estimate.

It should be taken into account that it is necessary to consider the purchasing managers' index in addition to other indicators. An important indicator in the analysis of the industrial sector of both separately considered enterprises and countries is the industrial production index.

The industrial production index is a macroeconomic indicator that characterizes the change in the production process with a set of services and goods grouped according to the following types of the all-Russian classifier of economic activities: "Manufacturing", "Mining Operations", "Production and distribution of electricity, gas and water."

Table 5 below shows the indicators of the industrial development index by country from 2010 to 2019 .

Table 5 Industrial development index by countries in the period from 2010 to $2019,2010=100$.

\begin{tabular}{|c|c|c|c|c|c|c|c|c|c|c|}
\hline Country & $\mathbf{2 0 1 0}$ & $\mathbf{2 0 1 1}$ & $\mathbf{2 0 1 2}$ & $\mathbf{2 0 1 3}$ & $\mathbf{2 0 1 4}$ & $\mathbf{2 0 1 5}$ & $\mathbf{2 0 1 6}$ & $\mathbf{2 0 1 7}$ & $\mathbf{2 0 1 8}$ & $\mathbf{2 0 1 9}$ \\
\hline Azerbaijan & 100 & 95.0 & 92.8 & 94.5 & 93.8 & 96.1 & 95.6 & 92.4 & 93.4 & 95.0 \\
\hline Germany & 100 & 107.1 & 106.2 & 106.1 & 107.5 & 109.0 & 110.5 & 113.5 & 114.6 & 109.5 \\
\hline Israel & 100 & 102.1 & 106.2 & 106.7 & 108.0 & 110.4 & 112.2 & 116.3 & 120.4 & 123.4 \\
\hline Italy & 100 & 100.4 & 94.4 & 91.5 & 90.5 & 92.1 & 93.4 & 96.2 & 97.6 & 96.6 \\
\hline Kyrgyzstan & 100 & 111.9 & 94.1 & 121.0 & 119.1 & 113.8 & 119.4 & 133.2 & 140.4 & 150.0 \\
\hline Lithuania & 100 & 106.6 & 110.9 & 114.2 & 114.5 & 119.5 & 122.8 & 131.4 & 137.8 & 142.4 \\
\hline $\begin{array}{c}\text { Poland } \\
\text { Republic of } \\
\text { Moldova }\end{array}$ & 100 & 106.7 & 108.0 & 110.6 & 114.4 & 119.9 & 123.3 & 131.4 & 139.2 & 145.0 \\
\hline $\begin{array}{c}\text { Russian } \\
\text { Federation }\end{array}$ & 100 & 105.0 & 108.5 & 110.5 & 113.2 & 114.8 & 116.3 & 117.2 & 120.6 & 123.7 \\
\hline $\begin{array}{c}\text { The United } \\
\text { Kingdom of } \\
\text { Great Britain } \\
\text { and Northern } \\
\text { Ireland }\end{array}$ & 100 & 100.0 & 97.6 & 96.6 & 98.1 & 99.1 & 100.3 & 102.3 & 102.7 & 101.7 \\
\hline $\begin{array}{c}\text { The United } \\
\text { States of } \\
\text { America }\end{array}$ & 100 & 103.1 & 106.1 & 108.2 & 111.6 & 110.8 & 109.4 & 106.5 &. .11 & $\ldots .1)$ \\
\hline \begin{tabular}{c} 
Uzbekistan \\
\hline Ukraine
\end{tabular} & 100 & 106.5 & 114.8 & 125.7 & 136.2 & 146.9 & 156.0 & 168.5 & 196.5 & $\ldots .1)$ \\
\hline
\end{tabular}




\begin{tabular}{|c|c|c|c|c|c|c|c|c|c|c|}
\hline France & 100 & 102.6 & 99.9 & 99.0 & 97.9 & 99.6 & 100.3 & 102.4 & 103.1 & 103.2 \\
\hline
\end{tabular}

Sources: Compiled using the statistical database of the United Nations Economic Commission for Europe. Access mode: https://w3.unece.org/PXWeb/en

Based on the data presented in Table 5, it can be seen that for each separately considered country, the industrial production index (adopted in 2010 as 100) has an ambiguous trend of both growth and decline. From the list of countries under consideration, it is clearly seen that the studied indicator in 2019 in comparison with 2010 has a negative downward trend in the following countries: Azerbaijan, Italy, and Ukraine. It is also worth noting that the following countries have the greatest growth in the index of industrial development in the period under study: Kyrgyzstan, Lithuania, Poland, the Republic of Moldova and Uzbekistan. This indicates a positive tendency in the industrial development of the countries and contributes to their further economic growth or to covering a possible decrease in volumes in other sectors.

\section{Discussion and Conclusion}

It should be noted that in order to timely identify a negative trend in the development of industry, it is necessary to conduct a general analysis of the main indicators of the industrial sector of the state in question in the context of other countries. When it comes to macroeconomic indicators affecting the development of Russian industry, it seems appropriate to compare such indicators as gross domestic product, purchasing managers' index and industrial production index. If the studied indicators have a positive development tendency and the industrial output itself appears to be promising, then the current development trend contributes to economic growth and independence of the state.

In general, Industry 4.0 and digitalization include the following components: smart sensors, 3D printing, big data analysis and the use of branched advanced algorithms, multilevel customer interaction, augmented reality (including using conventional client gadgets), various cloud services, mobile devices, IoT (Internet of Things), location technologies, improved human-machine interfaces, authentication and fraud detection. The introduction and use of all these technologies is reflected in the formation and development of the digital potential of an industrial enterprise and a cluster.

However, in the context of the digitalization of the economy, new models are needed for assessing the capabilities of enterprises to use advanced information and communication technologies, taking into account ensuring accessibility of these technologies, the skills of their application, the communication capabilities of networks and the qualifications of IT departments. In this regard, the study of economic relations between economic entities on the use of digital technologies in the framework of the activities of individual enterprises is of particular importance.

Thus, technology can have an important positive impact on national economies and their ability to achieve sustainable development goals, through effective governance mechanisms to integrate technology with three major stakeholder groups: individuals, businesses and governments. This factor is directly related to the development of Industry 4.0, which implies the modernization of production based on modern digital solutions and the creation of "smart" production that integrates individual objects into a coherent whole, which is the main stage for the subsequent automation and robotization of production.

The study was supported by the grant of the President of the Russian Federation for state support of the leading scientific schools of the Russian Federation NSh-2702.2020.6 "Conceptual Foundations of a New Paradigm of Economic Development in the Era of Technological and Social Transformation." 


\section{References}

1. Castiglione, C., Infante, D., Smirnova, J. (2015). Environment and economic growth: is the rule of law the go-between? The case of high-income countries. Energy, Sustainability and Society, 5(1).

2. Chen, J.-H., Chen, Y. (2015). New industry creation in less developed countries - The case of the Taiwanese flat panel display industry. Innovation-Management, Policy and Practice, 17(2), 250-265.

3. Dowlah, C. (2016). International trade, competitive advantage and developing economies: How less developed countries are capturing global markets. Routledge Studies in the Modern World Economy, 145, 1-260.

4. Vertakova, Y., Polozhentseva, Y., Klevtsova, M. (2016). Management of innovative processes in industry: Method of "road maps". In K. S. Soliman (Ed.), Proceedings of the 28th International Business Information Management Association Conference Vision 2020: Innovation Management, Development Sustainability, and Competitive Economic Growth (pp. 2168-2178). Seville, Spain: IBIMA.

5. Kuladzhi, T., Babkin, A., Murtazaev, S.-A. (2018). Matrix Tool for Efficiency Assessment of Production of Building Materials and Constructions in the Digital Economy. Advances in intelligent systems and computing, 692, 1333-1346.

6. Ács, J. Z., Varga, A. (2002). Geography, Endogenous Growth, and Innovation. International Regional Science Review, 25(1), 132-148.

7. Thissen, M., van Oort, F., Diodato, D., Ruijs, A. (2013). Regional Competitiveness and Smart Specialization in Europe. Cheltenham: Edward Elgar.

8. Tregenna, F. (2013). Deindustrialization and Reindustrialization. In A. Szirmai, W. Naudé, \& L. Alcorta (Eds.), Pathways to Industrialization in the Twenty-First Century (pp. 76-101). Oxford: Oxford University Press.

9. Weiss, J. (2002). Industrialisation and Globalisation. Theory and Evidence from Developing Countries. London: Routledge.

10. Bodrunov, S., Plotnikov, V. and Vertakova, Y. (2017). Technological Development as a Factor of Ensuring the National Security. In K. S. Soliman (Ed.), Proceedings of the 30th International Business Information Management Association Conference - Vision 2020: Innovation Management, Development Sustainability, and Competitive Economic Growth (pp.2666-2674). Madrid: IBIMA.

11. Tregenna, F. (2009). Characterising deindustrialisation: An analysis of changes in manufacturing employment and output internationally. Cambridge Journal of Economics, 3, 433-466.

12. Westkamper, E. (2014). Towards there-industrialization of Europe: A concept for manufacturing for 2030. Heidelberg: Springer.

13. Xu, L. D., Xu, E. L., Li, L. (2018). Industry 4.0: state of the art and future trends. International journal of production research, 56(8), 2941-2962.

14. Mueller, J. M., Kiel, D., Voigt, K.-I. (2018). What Drives the Implementation of Industry 4.0? The Role of Opportunities and Challenges in the Context of Sustainability. Sustainability, 10(1), 247.

15. Dalenogare, L. S., Benitez, G. B., Ayala, N. F., Frank, A. G. (2018). The expected contribution of Industry 4.0 technologies for industrial performance. International journal of production economics, 204, 383-394. 